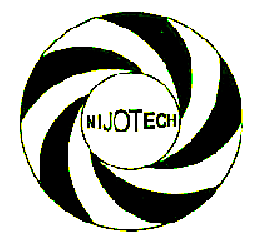

Nigerian Journal of Technology (NIJOTECH)

Vol. 34 No. 1, January 2015, pp. 48 - 55

Copyright@ Faculty of Engineering,

University of Nigeria, Nsukka, ISSN: $1115-8443$

www.nijotech.com

http://dx.doi.org/10.4314/njt.v34i1.6

\title{
EMPIRICAL MODELING OF OXYGEN UPTAKE OF FLOW OVER STEPPED CHUTES
}

\author{
S. Munta ${ }^{1,}$, D. B. Adie ${ }^{2}$ and I. Abubakar ${ }^{3}$

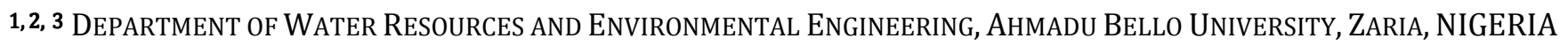 \\ E-mail Addresses:1muntjen2000@gmail.com,2donadie2005@yahoo.com, 3 abuismail1@yahoo.com
}

\begin{abstract}
The present investigation evaluates the influence of three different step chute geometry when skimming flow was allowed over them with the aim of determining the aerated flow length which is a significant factor when developing empirical equations for estimating aeration efficiency of flow. Overall, forty experiments were conducted in the Hydraulics Laboratory of the Department of Water Resources and Environmental Engineering, Ahmadu Bello University Zaria-Nigeria to determined the aeration efficiency of flow over the three different chute geometry at the water temperature $T$ and at the standard temperature of $20^{\circ} \mathrm{C}$. Data of the aeration parameters were analysed using a regression model to develop an empirical equation used for the prediction of aeration efficiency of flow for the three chute geometry under consideration. The results revealed that the aeration efficiency increases with an increased in the length of aeration but decreases with an increased in both the critical depth and roughness Froude number. The results also indicated that percentage of the length of aeration range from 51.6$71.4 \%$ over the stepped chute length for the range of unit discharge of 43.4-26.1 L/s.m. The aerated length in all the three chute geometry showed that they could contribute significantly to the overall aeration efficiency, especially the inclined chute type. The inclined chute configuration could be employed, optimally, as a water treatment structure.
\end{abstract}

Keywords: stepped chute, skimming flow, aeration length, macro-roughness, modeling

\section{INTRODUCTION}

Stepped cascades have been used for over 2,500 years [1]; for dissipation of high velocity of flow and aeration performance [2]. [3] Acknowledged that Aeration enhancement by macro-roughness is well known in water treatment, and one form is the aeration cascade. Stepped cascade (spillway) consists of an open channel with a series of steps that are built into the face (chute) of the spillway. The stepped chute aeration consists of using the available discharge head to create turbulence as the water falls in a thin film over series of concrete steps. Performance depends on the initial dissolved oxygen (DO) level, required discharge dissolved oxygen and water temperature. The reports in $[4,5,6]$ highlighted that the geometry of the stepped chute is a prime governing factor in order to enhance the aeration. The presence of air within high-velocity flows may prevent or reduce the damage of the chute caused by cavitation [7, 8]. Furthermore, [9, 10] have affirmed that air entrainment on stepped chutes re-oxygenates the water flow which contributes to the downstream river quality and the preservation of aerobic species.

Skimming flow is usually found for typical design discharges of stepped spillways [11] and that is why it was considered in this study; which was considered by [1] as a pseudo bottom defined by a straight line connecting the edges of each step. The skimming flow is attributed to air entrainment. According to $[12,13]$, skimming flow has two distinct regions over the length of the spillway chute viz: non-aerated and aerated regions which are separated by a critical point or point of inception. They further stressed that clear water was observed in the non-aerated region where the water enters the chute and white water in the aerated region which begins when the turbulent boundary layer from the floor intersects the water surface (Figure 1). 


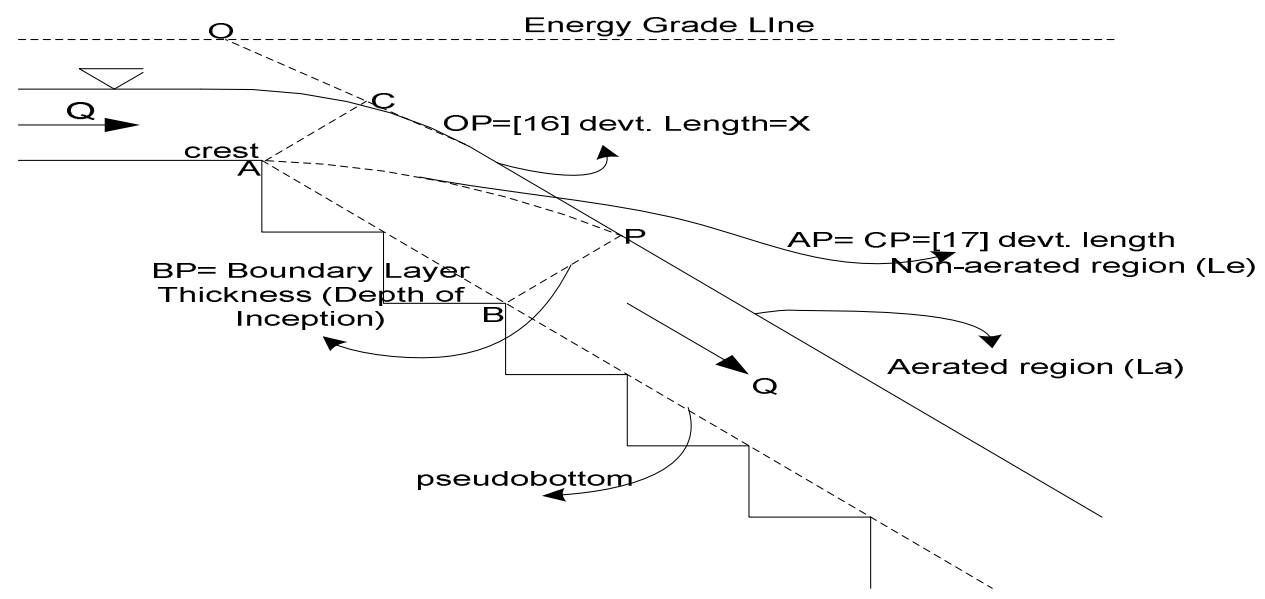

Figure 1: Air entrainment Flow Regimes (after [12, 13])

The aerated length is an important design variable in modeling the aeration efficiency of flow over the stepped spillway [14]. He further stressed that in order for the entrained air to curtail or prevent cavitation, very substantial parts of the chute length (the aerated length) has to contribute to the aeration process, which must influence the overall aeration efficiency. The aerated length can only be determined when the inception (development) length is known. From the studies of self aerated spillway flows, [15] concluded that the turbulent boundary layer or development length, caused by the stepped chute, initiated air entrainment when its thickness is approximately the depth of flow. A feasible equation was presented by [16] which overestimated the development length and was modified by [17]; for optimization purpose. This research used the modified inception length of [17] in order to determine the aerated length in this study.

The following three relations have been developed by [18], [19] and [20] respectively to determine the aeration efficiency of flow over stepped chutes, amongst which were:

$$
\begin{gathered}
E_{20}=1-\exp \left[\frac{-1.368+1.003\left(\frac{s}{h}\right)}{0.424+62.47 q^{2.148}\left(\frac{l}{h}\right)^{-0.928}}\right] \\
E_{20}=1-\left[1+2.16(\sin \alpha)^{0.290} 0.549\left(\frac{y_{c}}{h}\right)\right]^{-1} \\
E_{20}=1-\left[8.24 E-4 F_{*}^{1.65}+0.50 F_{*}^{1.34}\left(\frac{L_{a}}{h}\right)^{-1.34}\right. \\
\left.+2.23 E-2\left(\frac{L_{a}}{h}\right)^{-0.5}\right]^{0.28}
\end{gathered}
$$

In (1), (2) and (3), $E_{20}$ is the aeration efficiency normalized to the temperature of $20^{\circ} \mathrm{C}, \mathrm{h}$ is the stepped height, $\mathrm{l}$ is the stepped length, $\mathrm{s}$ is the sill height, $\alpha$ and $\theta$ are chute angles, $F_{*}=q / \sqrt{g \sin \theta h^{3}}$ is the stepped roughness height, $\mathrm{y}_{\mathrm{c}} \& \mathrm{~h}_{\mathrm{c}}$ are critical depth, $L_{a}$ is the aerated length. Eq. (1) is for end-sill chute while equations (2) and (3) are for plain chutes. Equations (1) and (2) cannot form the basis of comparison in this study because two of the design parameters used in the later developed aeration efficiency equations are lacking $\left(\mathrm{L}_{\mathrm{a}} / \mathrm{K}_{\mathrm{s}}\right.$ and $\mathrm{F} *$ ). Moreover, empirical equation of aeration efficiency over inclined chute is not available. This research focuses on developing empirical equation of the aeration efficiency of flow over plain, end-sill and inclined chute configurations, particularly, the effect of flow rate, stepped roughness height and the chute angle. Modeling of the aeration efficiency in this study will serve as a guide to the design of stepped spillway configurations and aeration process. Also, the three different chute geometry (plain, end-sill and inclined) used in this study will give engineers various options that they may consider in their choices for optimization purposes.

\section{MATERIALS AND METHODS}

\subsection{Physical models}

Ten physical models of stepped-channel chute designated as stepped spillway model (SSM) were built and fixed at the Hydraulics Laboratory of the Department of Water Resources and Environmental Engineering, Ahmadu Bello University, Zaria. The physical models were fabricated of wooden materials. The crest of the models was broad-crested [21]. The physical models dimension were selected based on the condition presented by [22], that skimming flow (Eq.4) and aeration (Eq. 5) would be attain when

$$
d_{c} / S_{h} \geq 0.91-0.14 \tan \theta
$$




$$
H_{d a m} / d_{c} \geq 15-20
$$

In (4) and (5), $H_{d a m}$ is the height of spillway model, $d_{c}$ is the critical depth, $S_{h}$ is the step height and $25<\theta<55$.

Refer to Figure 2 and Table 1 for the details of the stepped physical models where, $\mathrm{P}$ is the model height, $\mathrm{b}$ is the width of model, $\mathrm{S}_{\mathrm{h}}$ is the model step height, $\mathrm{K}_{\mathrm{s}}$ is the model roughness height, $\theta$ is the chute angle and $\mathrm{L}$ is the chute length.

\subsection{Experimental arrangement}

The aeration experiments were conducted in the Hydraulics Laboratory of the Department of Water Resources and Environmental Engineering of Ahmadu Bello University Zaria-Nigeria. A schematic representation of the experimental set-up is shown in Figures 3 and 4.

\subsection{Flow measurement}

A rectangular weir was incorporated to the outlet of the approach channel in order to measure the discharge in the channel. Water was admitted into the channel until a convenient maximum flow is obtained. The flow was collected in a container of a known volume after a particular time period; which is equivalent to the head of water over the weir measured at a point upstream of the weir using a depth gauge. The procedure was repeated by adjusting the valve in order to change the flow until desired readings were obtained

Table1: Geometry of the Developed Stepped Spillway Model (after [17]) for 26 steps, $P=104 \mathrm{~cm}$ and $b=15 \mathrm{~cm}$

\begin{tabular}{|c|c|c|c|c|}
\hline Model no. & $\mathrm{S}_{\mathrm{h}}(\mathrm{cm})$ & $\mathrm{K}_{\mathrm{s}}(\mathrm{cm})$ & $\theta$ (deg.) & $\mathrm{L}(\mathrm{cm})$ \\
\hline SSM-1 & 4 & 3.12 & 38.7 & 166.3 \\
\hline SSM-2 & 6 & 4.10 & 38.7 & 166.3 \\
\hline SSM-3 & 8 & 5.47 & 38.7 & 166.3 \\
\hline SSM-4 & 6 & 4.68 & 38.7 & 166.3 \\
\hline SSM-5 & 8 & 6.24 & 38.7 & 166.3 \\
\hline SSM-6 & 4 & 2.83 & 45 & 147 \\
\hline SSM-7 & 6 & 3.60 & 45 & 147 \\
\hline SSM-8 & 8 & 4.80 & 45 & 147 \\
\hline SSM-9 & 6 & 4.24 & 45 & 147 \\
\hline SSM-10 & 8 & 5.66 & 45 & 147 \\
\hline
\end{tabular}

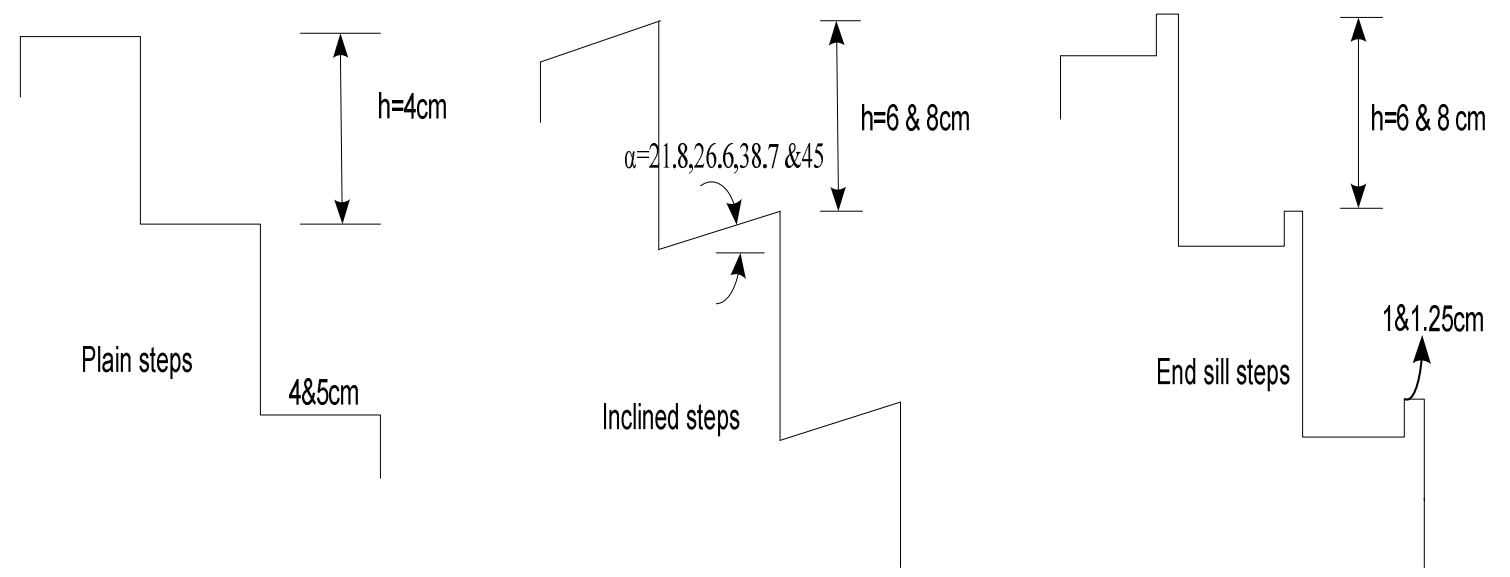

Figure 2: Side view of different steps configurations 
Figure 3: Set-up and Experimental performance of the Aeration Characteristics

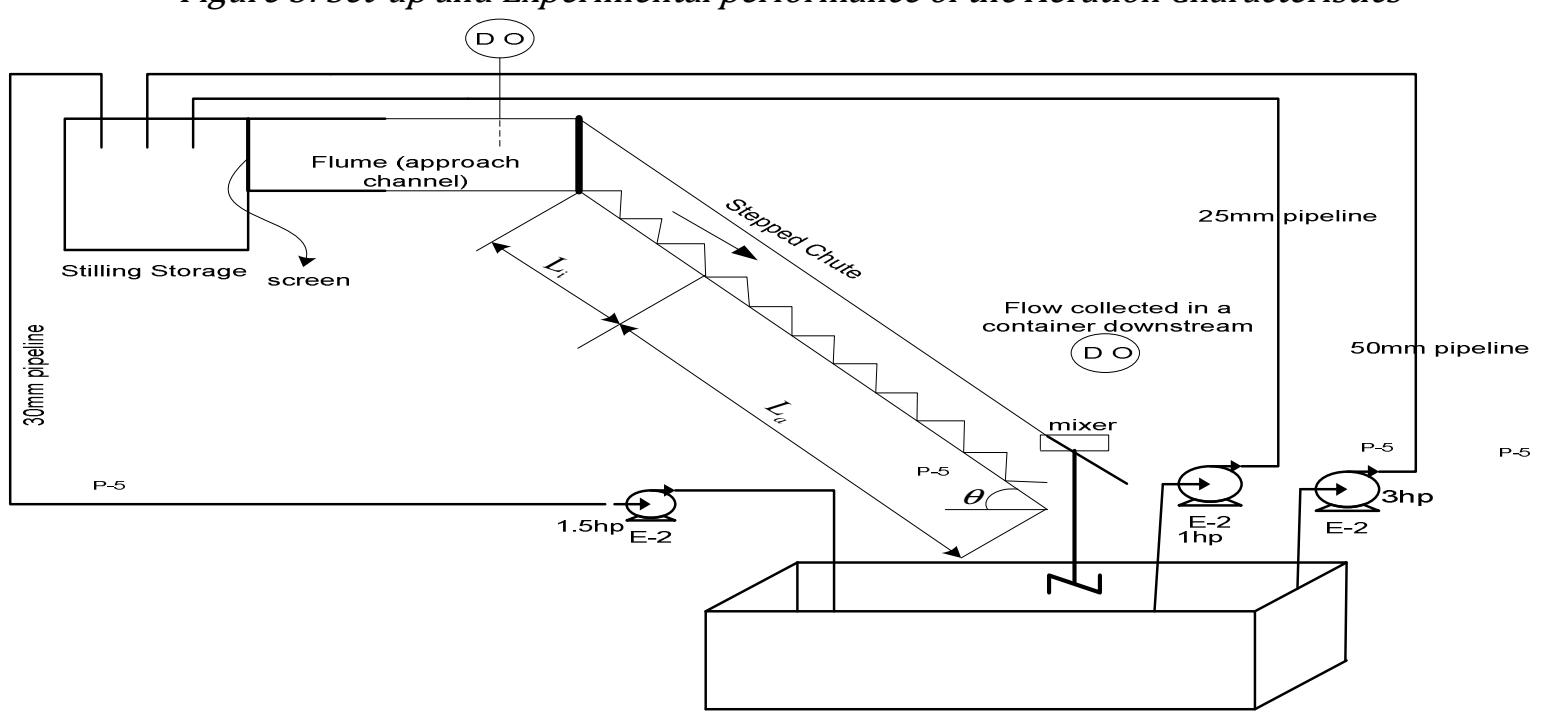

Figure 4: Experimental arrangement for stepped spillway model

The discharge-head relationship is of the form:

$$
Q=k H^{n}
$$

In (6), $\mathrm{Q}$ is the actual discharge, $\mathrm{L} / \mathrm{s} ; \mathrm{H}$ is the measured head, cm;

$$
\log Q=\log k+n \log H
$$

Graph of $\log \mathrm{Q}$ as a function of $\log \mathrm{H}$ is plotted on Microsoft Excel 2003 in order to determine the parameters $\mathrm{K}$ and $\mathrm{n}$ in Eq. (6).

\subsection{Determination of aeration efficiency}

Tap water in the workable basin was deoxygenated using sodium sulphite method; theoretically, $7.9 \mathrm{mg} / \mathrm{L}$ of sodium sulphite $\left(\mathrm{Na}_{2} \mathrm{SO}_{3}\right)$ is required to remove $1 \mathrm{mg} / \mathrm{L}$ of dissolve oxygen (DO). Based on the DO of the test tap water, the approximate sodium sulphite requirements were estimated (a 20\% excess used). Usually, addition of cobalt II chloride $\left(\mathrm{CoCl}_{2}\right)$ is required at a dosage of $3.3 \mathrm{mg} / \mathrm{L}$ as a catalyst for the de-oxygenation reaction. In this study, $34 \mathrm{~g}$ of sodium sulphite and 12g of cobalt II chloride were added into water for each experiment. Each experiment involved filling the workable basin with water; the temperature of the water was measured by using water thermometer, $\mathrm{Na}_{2} \mathrm{SO}_{3}$ and $\mathrm{CoCl}_{2}$ was added for chemical de-oxygenation and the DO measurement was carried out when the flow in the approach channel stabilizes. During the experiments, DO measurements upstream and downstream of the stepped cascade were measured using calibrated portable DISSOLVED OXYGEN METER Model MW600 at the locations identified in Figure 4. Measurements were made by submersing the probe to a depth of approximately $40 \mathrm{~mm}$ at sampling points. For accurate dissolved oxygen measurements, a minimum water movement of $0.3 \mathrm{~m} / \mathrm{s}$ was required. The DO meter was calibrated daily according to local atmospheric pressure, prior to use, by the zero calibration method. Calibration procedures followed those recommended by the manufacturer. In this study, the saturation concentration was determined from the manufacturer's chart. Oxygen transfer efficiency, E, at any temperature $\mathrm{T}$ is defined by [23] as"

$$
E=\frac{C_{d}-C_{u}}{C_{s}-C_{u}}
$$

In (8), $C_{u}$ and $C_{d}$ are upstream and downstream DO concentrations respectively; $C_{s}=D O$ saturation concentration. A transfer efficiency $\mathrm{E}=1.0$ means that the full transfer up to the saturation value has occurred at the structure. No transfer would correspond to $\mathrm{E}=0.0$.

To provide a uniform basis for comparison of measurement results, the aeration efficiency, often normalized to a temperature of $20^{\circ} \mathrm{C}$ standard, was also given by [23] (Eq. 9) to be:

$$
1-E_{20}=(1-E)^{1 / f}
$$

Where, $\mathrm{E}=$ transfer efficiency at actual water temperature $\mathrm{T} ; \mathrm{E}_{20}=$ transfer efficiency for $20^{\circ} \mathrm{C}$; and $\mathrm{f}$ $=$ exponent described as:

$$
\begin{aligned}
f=1.0+2.1 \times & 10^{-2}(T-20)+8.26 \\
& \times 10^{-5}(T-20)^{2}
\end{aligned}
$$

\subsection{Aeration efficiency equation}

Aeration performance depends on the initial dissolved oxygen (DO) level, required discharge dissolved 
oxygen, length of aeration $L_{a}$, acceleration due to gravity, g, critical depth $\mathrm{y}_{\mathrm{k}}$, step roughness height $\mathrm{K}_{\mathrm{s}}$ and water temperature, $\mathrm{T}$. Condensing the variables into non-dimensional groups, a relationship was developed for aeration efficiency normalized to the temperature of $20^{\circ} \mathrm{C}$ as:

$E_{20}=1-\left[1-a_{1}\left(\left|\frac{y_{k}}{K_{s}}\right|^{a_{2}},\left|\frac{L a}{K_{s}}\right|^{a_{3}}, F_{e}^{a_{4}}\right)\right]^{b}$

Where $\mathrm{L}_{\mathrm{a}}=\mathrm{L}-\mathrm{L}_{\mathrm{e}}$ is the aerated length; $\mathrm{L}_{\mathrm{e}}$ is the inception length of [17] given on Table 2, the constants $\mathrm{a}_{1}, \mathrm{a}_{2}, \mathrm{a}_{3}, \mathrm{a}_{4}$ are determined experimentally, $F_{e}=q / \sqrt{g K_{S}^{3}}$ is the roughness Froude number and $\mathrm{b}$ is a coefficient related to actual temperature given as: $b=\left[1.0+2.1 \times 10^{-2}(T-20)+8.26 \times 10^{-5}(T-20)^{2}\right]^{-1}$

Table 2: Inception Length (after [17])

\begin{tabular}{ccccc}
\hline \multirow{2}{*}{ Model No. } & \multicolumn{4}{c}{$\mathrm{q}(\mathrm{L} / \mathrm{s} . \mathrm{m})$} \\
\cline { 2 - 5 } & 26.1 & 31.1 & 35.6 & 43.4 \\
\hline SSM-1 & 51.1 & 58.5 & 63.8 & 73.8 \\
SSM-2 & 49.6 & 57.0 & 62.3 & 72.0 \\
SSM-3 & 48.2 & 55.4 & 60.8 & 70.1 \\
SSM-4 & 49.2 & 56.2 & 61.7 & 71.1 \\
SSM-5 & 47.6 & 54.9 & 60.1 & 69.3 \\
SSM-6 & 49.3 & 56.4 & 61.7 & 71.2 \\
SSM-7 & 48.1 & 55.0 & 60.2 & 69.9 \\
SSM-8 & 46.9 & 53.8 & 58.7 & 67.9 \\
SSM-9 & 47.2 & 54.3 & 59.3 & 68.8 \\
SSM-10 & 46.2 & 53.0 & 57.8 & 67.0 \\
\hline
\end{tabular}

\section{RESULTS AND DISCUSSION}

\subsection{Flow model}

Table 3 showed the values of the discharge and the head data, the log of the parameters were plotted on Microsoft excel 2003 (Fig.5) to determine $\mathrm{k}=0.33$ and $n=1.5$ of Equation (6), which is the flow model employed to run the aeration experiment.

\subsection{Aeration model}

The DO concentrations upstream and downstream of each model were measured at an altitude of $600 \mathrm{~m}$ above the sea level and at the temperature of $26^{\circ} \mathrm{C}$, which gives the oxygen saturation concentration of the tap water to be $7.5 \mathrm{~m} / \mathrm{L}$ from chart (Table 4).

Table 3: Measured Head and Flow Rate

\begin{tabular}{ccc}
\hline $\mathrm{S} / \mathrm{N}$ & $\mathrm{H}(\mathrm{cm})$ & $\mathrm{Q}(\mathrm{L} / \mathrm{s})$ \\
\hline 1 & 2.40 & 1.28 \\
2 & 3.50 & 2.16 \\
3 & 4.30 & 2.94 \\
4 & 5.10 & 3.91
\end{tabular}

Nigerian Journal of Technology,

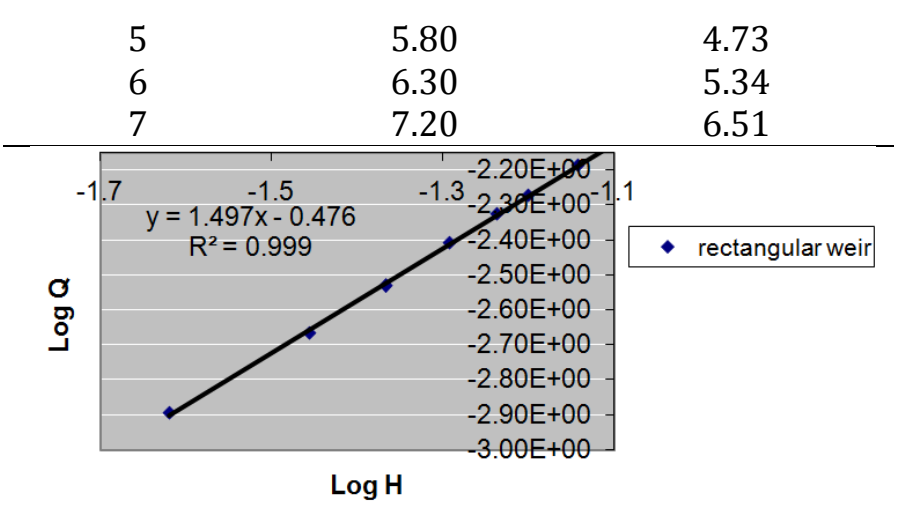

Figure 5: Head-Discharge Relationship

For every model, at a given unit discharge and at the standard temperature of $20^{\circ} \mathrm{C}$, the aeration parameters in Equation (11) were determined and plotted, as can be viewed in Figures 6a-8c. The aeration data in Figures 6a-8c were analyzed using a regression model to obtain the values of the constants $a_{1}, a_{2}, a_{3}, a_{4}$ in Equation (11), as shown on Table 5. Results in Figures 6a-6c, for the aeration efficiency as a function of the ratio of critical depth to the stepped roughness height, revealed that the Aeration efficiency $\mathrm{E}_{20}$ decreases as $\mathrm{y}_{\mathrm{k}} / \mathrm{K}_{\mathrm{s}}$ increases. This has confirmed with Eq. (5) of [22]; which indicated that critical depth increases with a decreasing value of aeration. Also, the result agrees with the statement of [24] that for all chute angle, aeration efficiency decreases with an increased in the ratio of critical depth to stepped height. The results in Figures 7a-7c, for the aeration efficiency as a function of the ratio of the length of aeration to the stepped roughness height, indicated that $\mathrm{E}_{20}$ increases as $\mathrm{L}_{\mathrm{a}} / \mathrm{L}_{\mathrm{s}}$ increases. [14] stated that length of aeration increases with an increase in overall aeration efficiency; this also agrees with the statement of [20] that aeration efficiency decreases with an increase in the ratio of non-aerated length to stepped height. Aeration efficiency in Figures 8a-8c showed that it decreases as roughness Froude number $\mathrm{F}_{\mathrm{e}}$ increases. Froude number is a function of the velocity; it is when the velocity is dissipated that aeration is enhanced; this agrees with the statement of [20] that aeration efficiency decreases with an increase in roughness Froude number.

\section{Table 4: Altitude compensation}

\begin{tabular}{llll}
\hline \multirow{2}{*}{ Altitude, meters above sea level } & \multicolumn{3}{l}{$\mathrm{C}$} \\
\cline { 2 - 4 } & 24 & 26 & 28 \\
\hline $0 \mathrm{~m}$ & 8.4 & 8.1 & 7.8 \\
$300 \mathrm{~m}$ & 8.1 & 7.8 & 7.5 \\
$600 \mathrm{~m}$ & 7.8 & 7.5 & 7.3 \\
$900 \mathrm{~m}$ & 7.5 & 7.3 & 7.0 \\
$1200 \mathrm{~m}$ & 7.3 & 7.0 & 6.8 \\
$1500 \mathrm{~m}$ & 7.1 & 6.8 & 6.6 \\
$1800 \mathrm{~m}$ & 6.8 & 6.6 & 6.3
\end{tabular}



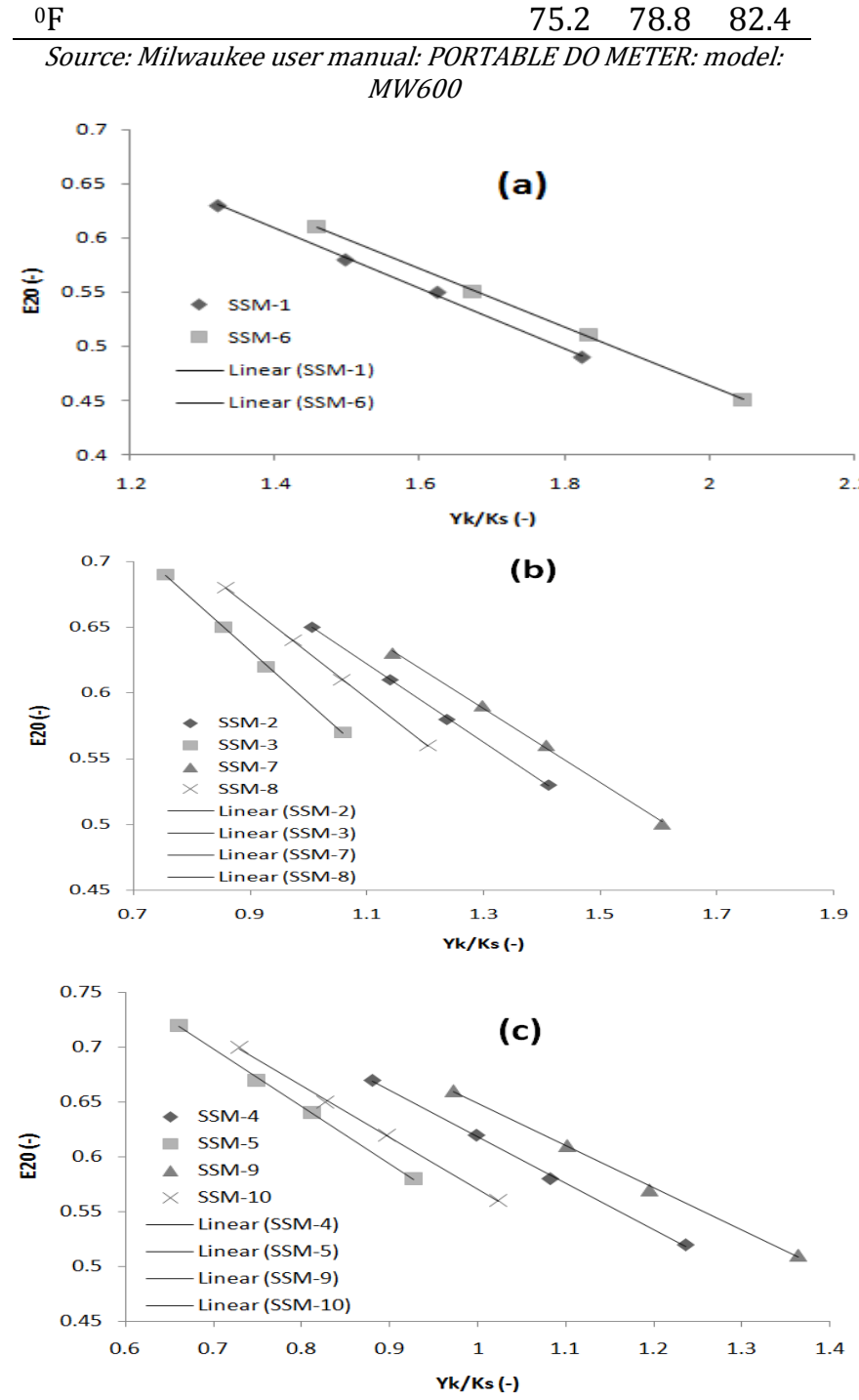

Figure 6: Aeration efficiency as a function of critical depth to stepped roughness height for; (a) plain chute; (b) end-sill chute; (c) inclined chute.

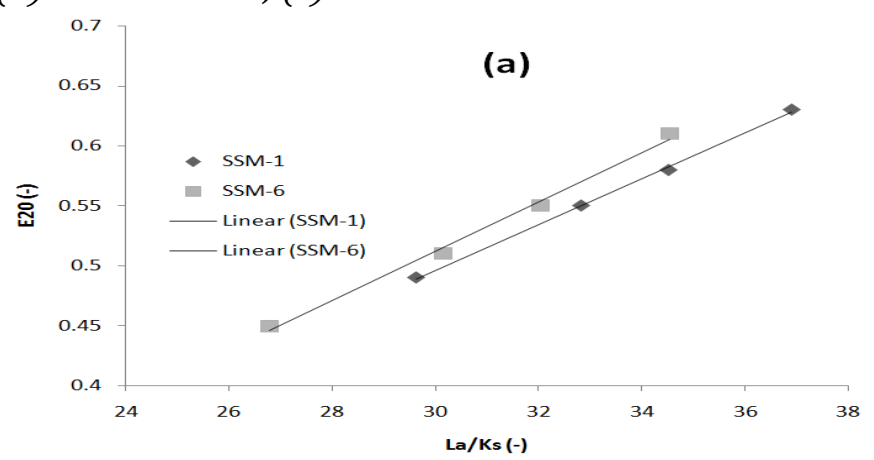

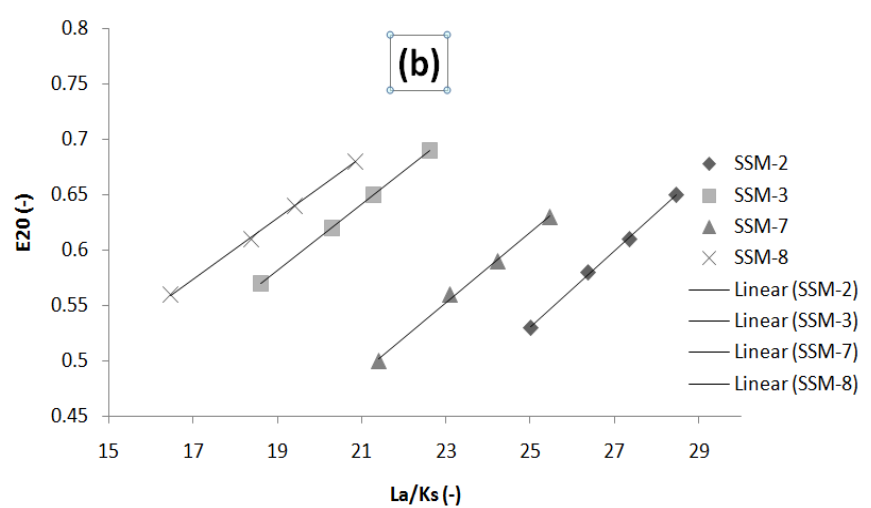

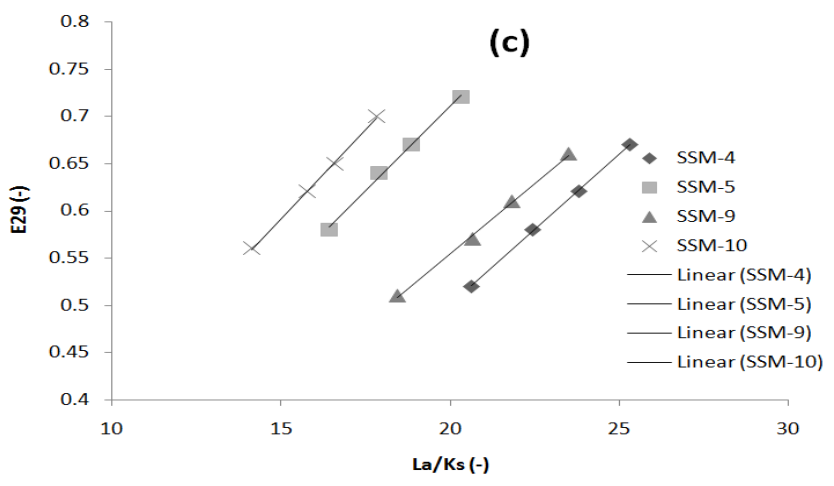

Figure 7: Aeration efficiency as a function of aeration length to stepped roughness height for; (a) plain chute; (b) end-sill chute; (c) inclined chute.
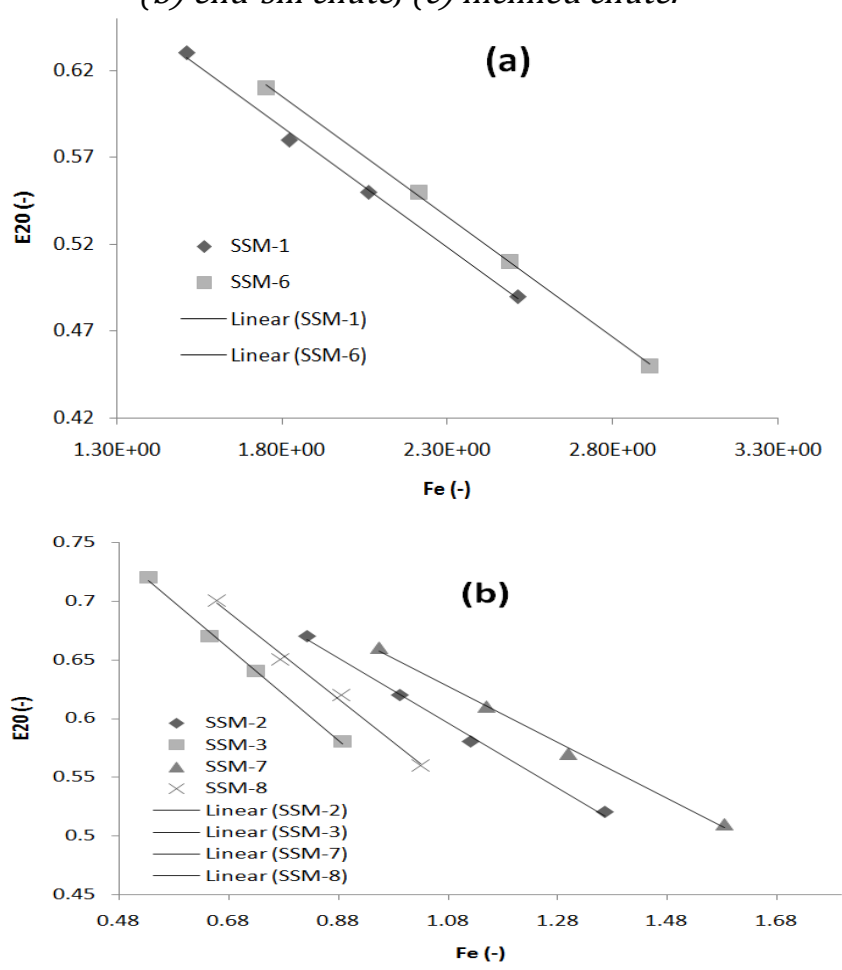


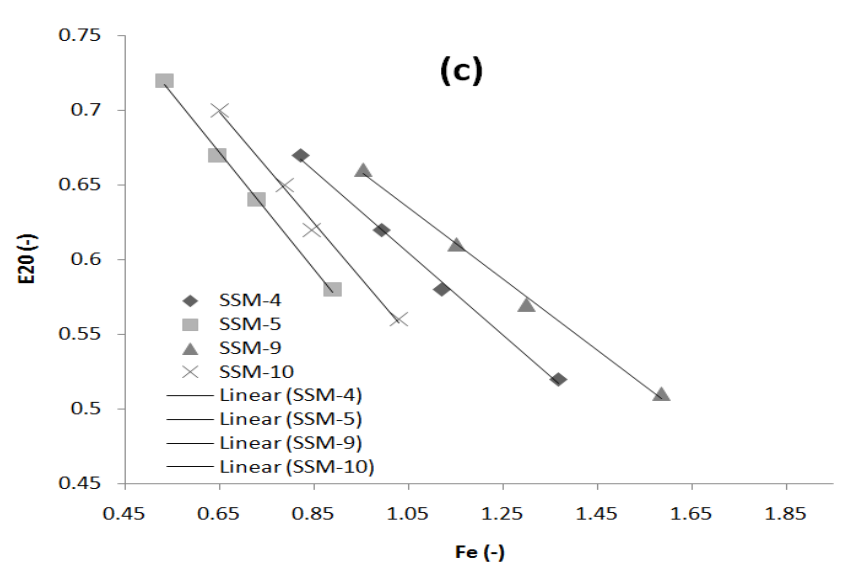

Figure 8: Aeration efficiency as a function of roughness Froude number for; (a) plain chute; (b) end-sill chute; (c) inclined chute.

\subsection{Model validation}

The developed aeration model of Equation (11) was validated, taking the unit discharge of $26.1 \mathrm{~L} / \mathrm{s} . \mathrm{m}$ and value of aeration efficiency for two models from each chute geometry as an example, there is good agreement between them, as shown on Table 7. The developed aeration efficiency in Equation (11) in the present study was also compared with that of [20] in Equation (3), as can be viewed on Table 6, showed that there is a good agreement between them.

Table 5: Values of constants in Eq. (11)

\begin{tabular}{cccc}
\hline Configuration & Plain & End-sill & Inclined \\
\hline $\mathrm{a}_{1}$ & 0.569 & 0.476 & 0.326 \\
$\mathrm{a}_{1}$ & 1.360 & 2.180 & -0.919 \\
$\mathrm{a}_{1}$ & 0.106 & 0.136 & 0.211 \\
$\mathrm{a}_{1}$ & -1.396 & -1.803 & 0.264 \\
$\mathrm{R}^{2}$ & 0.99 & 0.98 & 0.97 \\
\% error & 0.584 & 0.541 & 0.776 \\
\hline
\end{tabular}

Table 6: Comparison of predicted aeration efficiency in Eq. (11) with that of [20], Eq. (3)

\begin{tabular}{ccc}
\hline Authors $\rightarrow$ & {$[2]$} & Present study \\
\hline $\mathrm{q}(\mathrm{L} / \mathrm{s} . \mathrm{m})$ & 26.1 & 26.1 \\
$\theta(\mathrm{deg})$ & 38.7 & 38.7 \\
$\mathrm{~b}(\mathrm{~cm})$ & 30 & 30 \\
$\mathrm{Sh}(\mathrm{cm})$ & 10 & 8 \\
$\mathrm{~L}(\mathrm{~m})$ & 4.0 & 1.663 \\
$\mathrm{Le}(\mathrm{m})$ & 0.475 & 0.476 \\
$\mathrm{La}(\mathrm{m})$ & 3.525 & 1.189 \\
$\mathrm{E}_{20}(-)$ & 0.78 & 0.73 \\
\hline
\end{tabular}

[20]: Q(5-50L/s), $\theta\left(30-50^{\circ}\right), h(50,100 \& 100 \mathrm{~mm}), b=30 \mathrm{~cm}$

Table 7: Verification of measured aeration efficiency with that predicted from $\mathrm{Eq}$. (11) for $q=26.1 \mathrm{~L} / \mathrm{s} . \mathrm{m}$

\begin{tabular}{llll}
\hline Model & $\mathrm{E}_{20}($ expt.) & $\mathrm{E}_{20}(\mathrm{cal})$ & \%Diff \\
\hline SSM-1 & 0.63 & 0.64 & 1.56 \\
SSM-3 & 0.69 & 0.69 & 0 \\
SSM-5 & 0.72 & 0.73 & 1.37 \\
SSM-6 & 0.61 & 0.60 & 1.67 \\
SSM-8 & 0.68 & 0.67 & 1.49 \\
SSM-10 & 0.70 & 0.70 & 0 \\
\hline
\end{tabular}

\section{CONCLUSION}

Laboratory experiments were carried out on Stepped Spillway Model (SSM) with different chute geometry (plain, end-sill and inclined) to developed empirical equations for the prediction of aeration efficiency of the flows. Only empirical equations for plain and endsill chutes were developed by earlier researchers. Parameters that influence the aeration efficiency were also identified. Based on these findings, the following conclusions can be drawn:

1. Generally, aeration efficiency increases with an increase in stepped roughness height but decreases with an increase in both unit discharge and chute angle.

2. The results demonstrated that aeration efficiency $\mathrm{E}_{20}$ increases with an increase in the ratio of length of aeration to the stepped roughness height $\mathrm{L}_{\mathrm{a}} / \mathrm{K}_{\mathrm{s}}$ and decreases with an increase in both the ratio of critical depth to the stepped roughness height $y_{k} / K_{s}$ and the roughness Froude number $F_{e}$.

3. The three chute configurations used in this study could be employed as design models because the percentage of the length of aeration range from 51.6-71.4\% over the stepped chute length for the range of unit discharge of 43.4-26.1 L/s.m.

4. Aeration performance of inclined stepped types is more than that of the end-sill and plain types; hence they have the tendency to enhance more aeration into the flow than the other chute geometries.

5. Among the inclined, SSM-5 has the highest aeration efficiency value of $72 \%$ and performed optimally in the re-aeration of flow in the present study.

\section{REFERENCES}

[1] Chanson, H., "State of the Art of the Hydraulic Design of Stepped Chute Spillways", Hydropower Dams J., 1994, pp. 33-42.

[2] Chanson, H., "Historical Development of Stepped Cascades for the Dissipation of Hydraulic Energy, Trans. Newcomen, Soc., 72, 2000, pp. 295-318. 
[3] Toombes, L. and Chanson, H., "Air-water flow and gas transfer at aeration cascades" : A comparative study of smooth and stepped chutes. Proc. International Workshop on Hydraulics of Stepped Spillways, Balkema, Rotterdam, The Netherlands, 2000, pp. 77-84.

[4] Chanson, H., "Stepped Spillway Flows and Air Entrainment" , Canadian Journal of Civil Engineering, 20(3): 1993, 422-435.

[5] Pedro, M. B. L., "Free-surface flow interface and airentrainment modelling using OpenFOAM" , $\mathrm{PhD}$ thesis in Hydraulic, Water Resources and Environment, Departamento de Engenharia Civil, Faculdade de Ciencias E Tecnologia Universidade de Coimbra, 2013.

[6] Rathinakumar, V., Dhinakaran, G. and Suribabu, C. R., "Assessment of Aeration Capacity of Stepped Cascade System for Selected Geometry" , International Journal of ChemTech Research CODEN , Vol.6, No.1, 2014, pp 254-262.

[7] May, R.W.P., "Cavitation in Hydraulics Structures" : Occurrence and Prevention, Hydraulic Research Report, No. SR 79, Wallingford, United Kingdom, 1987.

[6] Bung, D.B. and Schlenkhoff, A., "Self-Aerated Skimming Flow On Embankment Stepped Spillways" The Effect of Additional Micro-roughness On Energy Dissipation And Oxygen Transfer. In: IAHR European Congress, 2010.

[9] Wilhelms, S. C. and Gulliver, J. S., "Self Aerating Spillway Flow" , Proceedings of the ASCE National Conference on Hydraulic Engineering, New Orleans, La., 1989, pp. 553-881.

[10] Chanson, H., "Prediction of the Transition Nappe/Skimming flow on a Stepped Channel" , J. Hydr. Res., IAHR, 34 (3), 1996, 421-429.

[11] Amador, A., Sánchez-Juny, $M$ and Dolz, J. "Characterization of the Nonaerated flow region in a stepped spillway by PIV", Transactions of the American Society of Civil Engineers, vol. 128, 2006, pp. 1266-1273.

[12] Falvey, H. T., "Air-Water Flow in Hydraulic Structures", Engineering Monograph No. 41: A Water Resources Technical Publication, Engineering and Research centre Denver, Colarado, 80225, 1980.

[13] Duangrudee, K., "Validation of numerical model of the flow behaviour through smooth and stepped spillways using large-scale physical model' , Phd dissertation (Civil Engineering) Faculty of Engineering, King Mongkut's University of Technology Thonburi, 2012.

[14] Novak P., "Improvement of water quality in rivers by aeration at hydraulic structure": In Water Quality and its Control (HINO M. (ed.), International Association of Hydraulic Research, Madrid, 1994.

[15] Wilhelms, S. C. and Gulliver, J. S., "Self-Aerated Flow on Corps of Engineers Spillways", Technical Report W-94-2, U.S. Army Corps of Engineers Washington, DC, 1994, 20314-1000.

[16] Bauer, W. J. "Turbulent boundary layer on steep slopes", Transactions of the American Society of Civil Engineers 119(2719), 1954, pp. 1212-1242.

[17] Munta, S. and Otun, J.A., " Study of the Inception Length of Flow over Stepped Spillway Models" , Nigerian Journal of Technology, Vol. 33, No. 2, 2014, pp. 176-183.

[18] Emiroglu, M.E.and Baylar, A., "An investigation of effect of stepped chutes with end sill on aeration performance" , Water Quality Research Journal of Canada, 38(3): 2003, pp. 527-539.

[19] Baylar, A. and Emiroglu, M.E., "Study of Aeration Efficiency at Stepped Channels", Proc. Inst. Civ. Engrs. Water \& Marit. Eng., 156 (WM3), 2005, 257263.

[20] Baylar, A., Emiroglu, M. E. and Bagatur, T., "An experimental investigation of aeration performance in stepped spillways" Water and Environment Journal, 20(1): 2006, pp. 35-42.

[21] Chanson,H., "Hydraulic Design of Stepped Cascades, Channels, Weirs and Spillways", Pergamon, Oxford, UK, 1995, 292.

[22] Boes,M. and Hager, W. H., "Two-phase Flow Characteristics of Stepped Spillway". J.Hydr. Engrg., ASCE, 129(9), 2003, pp. 661-670.

[23] Gulliver, J.S., Thene, J.R., Rindels, A.J., "Indexing gas transfer in self-aerated flows" , Journal of Environmental Engineering-ASCE, 116(3): 1990, 503-523.

[24] Baylar, A., Bagatur, T. and Emiroglu, M.E., "Prediction of oxygen content of nappe, transition and skimming flow regimes in stepped-channel chutes" , Journal of Environmental Engineering and Science, 6(2): 2007, 201-208. 